Ann. Zootech., 1980, 29, no h. s., 145-155.

\title{
The efficiency of energy utilisation by beef cattle
}

\author{
K.L. BLAXTER \\ The Rowett Research Institute, \\ Greenburn Road, Bucksburn, Aberdeen AB2 9SB (UK)
}

\begin{abstract}
The efficiency of utilisation of dietary energy may be defined as the slope of the relationship between the heat of combustion of the feed consumed and that of the fat and protein stored in the body. It is the product of the metabolisability of feed energy and the efficiency with which metabolisable energy is used, neither of which are constants, varying with the amount and composition of the diet given. The overall relationship between feed intake and energy retention is outlined and the derivation of its parameters described. These relationships can be used to predict gain in cattle and examples are given of the application of this approach to cattle given extreme diets of barley or of forage. The above approach assumes that the determinants of efficiency are attributes of diet. From results obtained with simple-stomached species it seems likely, however, that efficiency in cattle should also vary with the composition of their gains and particularly with the ratio of fat : protein stored. Evidence that efficiency varies with the composition of gain in ruminants is, however, very conflicting. It is possible that the variable results obtained reflect problems of estimation of the two terms, efficiency of utilisation of energy for fat and protein deposition in these species.
\end{abstract}

\section{Résumé}

\section{Rendement d'utilisation de l'énergie par les bovins pour la production de viande}

Le rendement d'utilisation de l'énergie des rations peut se définir comme le coefficient de régression de l'énergie fixée dans l'organisme sous forme de lipides et de protéines, en fonction de la quantité d'énergie brute ingérée. C'est le produit de la concentration en énergie métabolisable (EM) de la ration par le rendement d'utilisation de l'E.M., ces 2 facteurs variant avec la composition de la ration.

L'auteur présente les grandes lignes de la relation générale entre l'énergie fixée et l'énergie brute ingérée et le calcul des différents termes. Ces relations permettent de prévoir le gain de poids des bovins, comme le montrent des exemples correspondant à des rations extrêmes, d'orge ou de foin.

Cette approche suppose que les facteurs du rendement dépendent seulement des caractéristiques de la ration. Cependant, compte tenu des résultats obtenus chez les animaux monogastriques, il est probable que chez les bovins le rendement d'utilisation de l'énergie varie avec la composition du gain et en particulier avec le rapport lipides fixés/protéines fixées. Les résultats cependant sont contradictoires chez les ruminants, ce qui peut résulter des difficultés d'estimation des rendements d'utilisation de l'énergie pour la fixation de lipides ou de protéines. 
When the amount of feed consumed each day by a beef animal is increased the energy retained in its body increases. The increment of energy retained per unit increase in feed energy provided, that is the partial efficiency of energy utilisation, $k$, does not however remain constant. As intake is increased from fasting to full feed partial efficiency declines and the fall is continuous without any clear-cut discontinuities.

This relationship has been known for a long time (BLAXTER and Graham, 1955) and in several feeding systems attempts have been made to take at least some account of it. The most common one is to ascribe different efficiencies below maintenance and above maintenance, that is to approximate the curvilinear relationship between energy retention and energy intake by two linear ones intersecting at maintenance. This is exemplified by the UK metabolisable energy system (MAFF, DAFS and DANI, 1975), the French system (JARRIGE, 1978) and by the Californian net energy system (LOFGREEN and GARRETT, 1968). Greater refinement comes about by the inclusion of a level of feeding correction such as that in the original ARC (1965) system from which the UK system derives. Some systems, such as that in the German Democratic Republic (SchiemanN et al., 1971), implicitly take no account of change in efficiency at all, or alternatively the requirements of energy per unit gain are increased at the higher rates of gain, in an attempt to impart curvilinearity. This is to ensure that prediction of weight gain accords more closely with practical experience.

None of these attempts to make linear a relationship which is basically nonlinear is entirely satisfactory. The division of the continuously varying efficiency, $k$, into two components, $k_{m}$ efficiency of utilising metabolisable energy for maintenance and $k_{f}$ efficiency for growth and fattening, which are constant for a particular diet but which vary from diet to diet, has probably been the most successfu! approach.

It is now suggested that it is sensible to discard attempts to linearise the relationship and to accept that energy retention is curvilinearly related to energy intake. In this respect, the relationship of practical interest is that between the mass of feed ingested or its measured heat of combustion and energy retention rather than between an estimated quantity of metabolisable energy or digested energy and energy retention. In addition, a relationship established from measurements of metabolisable energy (ME) and energy retention $(\mathrm{R})$ is open to bias since the determinations of fecal, urinary and gaseous losses of energy contribute errors to both ME and R. For these reasons Mr. Boyne and I (BLAXTER and BOYNE, 1978) analysed the relationship between energy retention and gross energy intake in 80 calorimetric experiments involving about 800 determinations of energy retention to obtain estimates of partial efficiency of utilisation of the gross energy of feed. Declines in efficiency with increasing level of feeding thus includes any decline in the metabolisability of feed with increase in feeding level as well as the decline (which presumably reflects a series of complex factors relating to the balance of endergonic and exergonic processes, substrate supply and utilisation) associated with the utilisation of increased quantities of energyyielding nutrients absorbed.

The basic approach used was to describe the relationship by a general equation :

$$
\mathrm{R}=\mathrm{B}(1-\exp (-\mathrm{pG}))-1 \ldots \ldots \ldots
$$

where $\mathbf{R}=$ energy retention scaled by division by the animal's measured fasting metabolism, F 
$\mathrm{G}=$ gross energy intake scaled by division by the animal's measured fasting metabolism

$\mathrm{B}$ and $\mathrm{p}$ are constants.

The two constants $B$ and $p$ are characteristics of the diet used. Equation (1) allows direct estimation of energy retention from feed intake and algebraic rearrangement allows the reverse, direct estimation of feed intake for a given energy retention, viz :

$$
\mathrm{G}=\frac{1}{p} \log \left(\frac{\mathrm{B}}{\mathrm{B}-\mathrm{R}-1}\right)
$$

Equations (1) and (2) are the basic relationships needed in diet assessment.

From equation (1) it is clear that efficiency of utilisation of gross energy declines from a maximal value of $\mathrm{Bp}$ as the amount of feed consumed is increased with a rate constant of $p$. The basic equation can be further manipulated to measure efficiency in the more usual way, namely efficiency for maintenance, that is the average slope from fasting to maintenance (zero energy retention) and for growth and fattening above maintenance. In the latter instance it is convenient to define the feeding levels over which efficiency for growth and fattening is measured to be from maintenance to twice maintenance. Then :

$$
\begin{aligned}
& \begin{array}{l}
\text { Efficiency of } \\
\text { utilisation of } \\
\text { gross energy } \\
\text { for maintenance }
\end{array} \\
& \quad=\mathrm{E}_{\mathrm{G}, m}=\frac{p}{\log \frac{\mathrm{B}}{\mathrm{B}-1}} \\
& \begin{array}{l}
\text { Efficiency of } \\
\text { utilisation of } \\
\text { gross energy for } \\
\text { growth and fattening }
\end{array} \quad=\mathrm{E}_{\mathrm{G}, f}=\frac{p(\mathrm{~B}-1)}{\mathrm{Blog} \frac{\mathrm{B}}{\mathrm{B}-1}}
\end{aligned}
$$

These two gross efficiencies can be converted into efficiencies of utilisation of metabolisable energy by dividing them by the metabolisability of the gross energy.

$$
\begin{aligned}
& \begin{array}{l}
\text { Efficiency of } \\
\text { utilisation of } \\
\text { metabolisable energy } \\
\text { for maintenance }
\end{array}=k_{m}=\frac{\mathrm{E}_{\mathrm{G}, m}}{q^{*}} \\
& \quad \begin{array}{l}
\text { Efficiency of } \\
\text { utilisation of } \\
\text { metabolisable energy }
\end{array}=k_{f}=\frac{\mathrm{E}_{\mathrm{G}, f}}{q^{*}} \\
& \text { for growth and fattening }
\end{aligned}
$$

where $q^{*}$ is the metabolisable energy as a proportion of the gross energy measured precisely at maintenance. In equations (5) and (6) $k_{m}$ and $k_{f}$ have the same significance that they have in the scheme of the ARC (1965) except that the $k_{f}$ term is measured at exactly twice the maintenance level of feeding and includes a component describing the fall in metabolisability of the gross energy as level of feeding is increased. It is thus slightly lower than $k_{f}$ estimated from observed values of ME and $\mathrm{R}$ above maintenance. 
In a converse way, the two primary constants of equation (1), B and p, can be estimated from the efficiencies if these are known :

$$
\begin{aligned}
& \mathrm{B}=\frac{k_{m}}{k_{m}-k_{f}}=\frac{\mathrm{E}_{\mathrm{G} \cdot m}}{\mathrm{E}_{\mathrm{G}, m}--\mathrm{E}_{\mathrm{G}, j}} \\
& p=\frac{k_{m}}{q^{*}} \log \frac{k_{m}}{k_{f}}=\mathrm{E}_{\mathrm{G}, m} \log \frac{\mathrm{E}_{\mathrm{G}, m}}{\mathrm{E}_{\mathrm{G}, f}}
\end{aligned}
$$

The analysis by BLAXTER and Boyne has shown that efficiencies of utilisation of gross energy (and hence efficiencies of utilisation of metabolisable energy and the two constants $\mathrm{B}$ and $p$ ) can be predicted from a knowledge of metabolisability, $q^{*}$, and the protein $(\mathrm{N} \times 6.25)$ content of the organic matter $(\mathrm{P}, \mathrm{g} / \mathrm{kg})$ :

$$
\begin{aligned}
& \mathrm{E}_{\mathrm{G}, m}=0.947 q^{*}-0.00010 \mathrm{P}-0.128 \quad \ldots \ldots \ldots \\
& \mathrm{E}_{\mathrm{G}, f}=0.951 q^{*}+0.00037 \mathrm{P}-0.336 \quad \ldots \ldots \ldots
\end{aligned}
$$

Values of $k_{m}$ and $k_{f}$ computed from these two equations are given in abridged form in Table 1 and derived values of $\mathrm{B}$ and $p$ in Table 2. Values of $k_{m}$ and $k_{f}$ can also be estimated from $q^{*}$ and fibre content.

It will be noted from Table 1 that the efficiency terms agree with those given by the ARC (1965) and for maintenance by VAN ES (1978). Efficiency for maintenance declines as protein content increases, a finding in agreement with observations summarised by VAN Es (1975). For production purposes efficiency increases as protein level increases.

\begin{tabular}{|c|c|c|c|c|}
\hline & $\begin{array}{c}\text { Metabolisability } \\
\text { of gross energy } \\
\mathrm{q}^{*}\end{array}$ & $\begin{array}{l}\text { Prote } \\
\text { of org } \\
\text { of } d i \\
100\end{array}$ & $\begin{array}{l}\text { content } \\
\text { matter } \\
(\mathrm{g} / \mathrm{kg}) \\
200\end{array}$ & $\operatorname{ARC}(1965)^{+}$ \\
\hline \multirow{4}{*}{$\mathrm{k}_{\mathrm{m}}$} & 0.4 & 0.602 & 0.578 & 0.666 \\
\hline & 0.5 & 0.670 & 0.650 & 0.696 \\
\hline & 0.6 & 0.717 & 0.700 & 0.726 \\
\hline & 0.7 & 0.750 & 0.736 & 0.756 \\
\hline \multirow{4}{*}{$\mathrm{k}_{\mathrm{f}}$} & 0.4 & 0.203 & 0.296 & 0.354 \\
\hline & 0.5 & 0.354 & 0.428 & 0.435 \\
\hline & 0.6 & 0.453 & 0.515 & 0.516 \\
\hline & 0.7 & 0.524 & 0.577 & 0.597 \\
\hline
\end{tabular}

TABLE I

EFFICIENCIES OF UTILISATION OF METABOLISABLE ENERGY FOR MAINTENANCE $\left(k_{m}\right)$ AND GROWTH AND FATTENING $\left(k_{f}\right)$

$$
\begin{aligned}
{ }^{+} \mathrm{k}_{\mathrm{m}} & =0.30 \mathrm{q}^{*}+0.546 \\
\mathrm{k}_{f} & =0.81 \mathrm{q}^{*}+0.030
\end{aligned}
$$

The errors attached to the values of $k_{m}$ and $k_{f}$ are approximately 0.04 . 
TABLE 2

VALUE OF THE CONSTANTS B AND p IN THE EQUATION (1) CALCULATED FROM EQUATIONS (9) AND (10)

\begin{tabular}{cccccc}
$\begin{array}{c}\text { Metabolisability } \\
\text { of gross energy } \\
\mathrm{q}^{*}\end{array}$ & \multicolumn{4}{c}{$\begin{array}{c}\text { Protein content of organic matter } \\
(\mathrm{p}, \mathrm{g} / \mathrm{kg})\end{array}$} \\
\hline 0.4 & $\mathrm{~B}$ & $\mathrm{p}$ & $\mathrm{B}$ & $\mathrm{p}$ \\
0.5 & 1.5495 & 0.2496 & 2.1292 & 0.1464 \\
0.6 & 2.1785 & 0.2061 & 3.0421 & 0.1297 \\
0.7 & 2.8192 & 0.1885 & 3.9792 & 0.1216 \\
\hline
\end{tabular}

The overall relationship can be used to predict gain, provided that the fasting metabolism and heat of combustion of gains is known. The basic equation can be stated as a differential equation :

$$
\frac{d \mathrm{~W}}{d t}=\frac{\mathrm{R}\left(a \mathrm{~W}^{n}\right)}{c}=\frac{a \mathrm{~W}^{n}}{c}-\left(\mathrm{B}\left(1-\exp \left(-p \mathrm{G}^{1} / a \mathrm{~W}^{n}\right)\right)-1\right)
$$

where $a \mathrm{~W}^{n}$ is the function of body weight (W) which describes fasting metabolism, $c$ is the heat of combustion of the gains (which is also a function of $\mathrm{W}$ for cattle of different breeds and sexes), and $\mathrm{G}^{1}$ is the actual heat of combustion of the feed consumed.

No algebraic solution to the integral of this equation has been found. It can, however, be integrated numerically ; the increment of gain in weight on the first day is added to the weight of the animal on the first day to obtain a new body weight from which the fasting metabolism and the heat of combustion of gains on the second day can be computed. The process is then repeated.

Using this approach and knowing only the initial weight of the animal and the amount and quality of the feed consumed each day it is possible to compute the course of body weight during growth and fattening. This has been done for extreme rations of all grain (barley) and all roughage, for castrated beef animals of the Friesian and Hereford $x$ Friesian breeds. Fasting metabolism was described by the same relationship for both breeds and the heat of combustion of gains was derived from an analysis of published data undertaken by the ARC (1979) Working Party on ruminant nutrient requirements. An abridged account of these latter relationships has been published (WEBSTER, 1978) as far as empty weight relationships are concerned. The computations were made using data for 118 individual animals in two experiments ; all the integrations were carried out for periods of over 80 days, most of them for over 300 days and some for more than 600 days. The results of the two experiments are summarised in Table 3. They show good agreement.

This raises questions about the extent of systematic errors in the components of the system - fasting metabolism, heat of combustion of gains and the efficiency of utilisation of feed energy. Table 4 shows the effect of a \pm 10 per cent variation in these on predicted growth.

Table 4 indicates that at high rates of gain imprecision in estimating fasting metabolism has relatively little effect on gain, and neither does efficiency of 
TABLE 3

COMPARISON OF OBSERVED GAINS BY BEEF CATTLE AND THOSE CALCULATED BY NUMERICAL INTEGRATION OF EQUATION (1l) (see text). THE TWO EXPERIMENTS WERE UNDERTAKEN BY M. KAY AND M. CRABTREE AT THE ROWETT INSTITUTE AND THE BASIC DATA CONSISTED OF RECORDS OF MEAN DAILY INTAKE OF FEED EACH WEEK, AND THE COMPOSITION OF THIS FEED

\begin{tabular}{|c|c|c|c|c|c|}
\hline $\begin{array}{l}\text { Observed } \\
\text { weight } \\
\text { gain }\end{array}$ & $\begin{array}{l}\text { Diet and } \\
\text { experiment }\end{array}$ & $\begin{array}{l}\text { No. of } \\
\text { animals }\end{array}$ & $\begin{array}{c}\text { Mean discrepancy } \\
\text { (calculated - } \\
\text { observed) kg }\end{array}$ & $\begin{array}{l}\text { Standard } \\
\text { deviation } \\
( \pm \mathrm{kg})\end{array}$ & $\begin{array}{c}\text { Days taken } \\
\text { to gain } \\
200 \text { or } \\
300 \mathrm{~kg} \\
\text { (range) }\end{array}$ \\
\hline 200 & Barley (1) & 23 & $+16.6 \pm 6.1$ & 29.1 & $196-308$ \\
\hline 200 & Barley (2) & 13 & $-1.0 \pm 4.7$ & 17.0 & $224-389$ \\
\hline 200 & Grass (1) & 32 & $+6.5 \pm 7.3$ & 41.1 & $188-378$ \\
\hline 200 & Grass (2) & 13 & $\begin{array}{l}-16.8 \pm 4.8 \\
n+4.4 . \text { Coverest }\end{array}$ & 17.3 & $\begin{array}{l}196-462 \\
.28)\end{array}$ \\
\hline 300 & Barley (1) & 5 & $+31.6 \pm 13.4$ & 30.2 & $350-476$ \\
\hline 300 & Barley (2) & 13 & $+1.9 \pm 8.2$ & 29.4 & $343-609$ \\
\hline 300 & Grass (1) & 11 & $+11.0 \pm 8.9$ & 29.4 & $386-686$ \\
\hline 300 & Grass (2) & 13 & $\begin{array}{l}-10.7 \pm 9.4 \\
n+4.0 \text { loveresti }\end{array}$ & $\begin{array}{l}33.8 \\
\text { nation by } 1\end{array}$ & $\begin{array}{l}329-672 \\
38)\end{array}$ \\
\hline
\end{tabular}

TASLE $\epsilon_{i}$

THE EFFECT OF a $\pm 10 \%$ VARIATION IN THE BASIC PARAMETERS OF THE EQUATIONS ON PREDICTED GAIN OF BEEF CATTLE. THE RESULTS APPLY TO A 300 KG CASTRATED ANTMAL GIVEN $7 \mathrm{~kg} /$ day OF A DIET WITH A METABOLISABILITY ( ${ }^{*}$ ) OF 0.60 AND A PROTEIN CONTENT OF $150 \mathrm{~g} / \mathrm{kg}$ ORGANIC MATTER FOR A PERIOD OF 100 DAYS ${ }^{+}$

\begin{tabular}{|c|c|c|}
\hline \multirow[t]{2}{*}{ Parameter varied } & \multicolumn{2}{|c|}{$\begin{array}{l}\text { Weight gain relative to } \\
\text { control when parameter }\end{array}$} \\
\hline & decreased 108 & increased $10 \%$ \\
\hline Fasting metabolism & 1.03 & 0.96 \\
\hline $\begin{array}{l}\text { Heat of combustion } \\
\text { of gains }\end{array}$ & 1.10 & 0.92 \\
\hline $\begin{array}{l}\text { Efficiency for } \\
\text { maintenance }\left(\mathrm{k}_{\mathrm{m}}\right)\end{array}$ & 0.96 & 1.01 \\
\hline $\begin{array}{l}\text { Efficiency for } \\
\text { production }\left(k_{f}\right)\end{array}$ & 0.92 & 1.08 \\
\hline Both efficiencies $k_{m}$ and $k_{f}$ & 0.89 & 1.10 \\
\hline
\end{tabular}


utilisation of energy for maintenance. The single most important factor determining precision is efficiency for growth and fattening.

The standard deviation of gains given in Table 3 do not vary greatly or systematically. They include variation due to the individuality of animals in their fasting metabolism, in their efficiency and in the composition of their gains. They also include any error arising from inaccuracy in estimating body weight and hence liveweight gain. From knowledge of the errors associated with estimating body weight due to changes in gut fill it is clear that the major part of the error in Table 3 arises from the technical difficulty of estimating gain in body weight. Had there been systematic error then the mean difference between calculated and observed gains for the two diets would have deviated significantly from zero. This approach thus appears to predict gain with reasonable precision from feed composition if fasting metabolism can be predicted from body weight and the composition of gain can be predicted from body weight and rate of gain.

The above approach states, however, that the only factors which affect the efficiency of utilisation of dietary energy are those which reflect the attributes of the diet - its metabolisability and its protein content, and that the breed, age, or body size of the animal do not affect these efficiencies. These animal attributes are, of course, included in the overall relationship between feed intake and weight gain since they determine fasting metabolism and the heat of combustion of gains in weight. Both vary with breed and age or weight or rate of growth, but the only factors which affect the efficiency terms are dietary ones.

Work with simple-stomached species has shown that above maintenance efficiency of utilisation of metabolisable energy can be regarded as consisting of two components, one relating to fat deposition and one to protein deposition (Kielanowski, 1976 ; Pullar and Webster, 1977 ; Mulier and KirCHGESSNER, 1979). The usual method employed to estimate these two efficiencies has been to estimate the coefficients in the equation :

$$
\mathrm{I}=a+b_{1} \mathrm{~F}+b_{2} \mathrm{P}
$$

where $I$ is the intake of metabolisable energy, $F$ the energy retained as fat and $P$ the energy retained as protein. Then $a$ is identified as the maintenance requirement, $b_{1}$ the efficiency of utilising metabolisable energy for deposition of energy as fat, and $b_{2}$ the efficiency of utilising energy for deposition of energy as protein. Estimates of $b_{1}$ and $b_{2}$ vary, largely because of the close correlation between $\mathrm{F}$ and $\mathrm{P}$, but also because of the problems of estimating protein deposition using $\mathrm{N}$ balance methods (overestimation of retention depresses the value of $b_{2}$ ). Even so, most values for fat efficiency in simple-stomached species are in the region of 0.70 and for protein deposition in the region of 0.45 . The former value is in agreement with stoicheometric calculations for the synthesis of triacyl-glycerols from glucose, but the latter is considerably less than the theoretical value calculated from knowledge about the energy required as ATP and GTP for the formation of peptide bonds. There is some evidence in pigs that the efficiency for protein deposition declines with increasing body weight as animals grow (BERSCHAUER et al., 1979). This approach suggests that major determinants of the efficiency of utilisation of metabolisable energy are the proportions of fat and protein deposited.

There are few estimates of the separate efficiencies of fat and protein deposition in ruminants and these are summarised in Table 5. ØRSKOV and MCDONALD (1970) working with early weaned lambs given diets of barley and soyabean meal and growing at rates of $95-337 \mathrm{~g} /$ day to body weights of $40 \mathrm{~kg}$ and using comparative slaughter methods found the efficiency of utilisation of metabolisable energy for 
fat deposition to be 0.80 and for protein deposition 0.34. Maintenance requirement was $420 \mathrm{~kJ} / \mathrm{kg} \mathrm{W}^{0.75}$. RATTRAY and JoYCE (1976) on analysing a series of 11 trials with 6-month old lambs found the efficiencies of both fat and protein deposition to vary appreciably from trial to trial. Maintenance requirements also varied considerably. The values in Table 5 , where the ME required to deposit $1 \mathrm{~g}$ fat or protein is given rather than efficiencies, are those which were thought to best summarise their data. BICKEL and DURRER's (1974) results were obtained with growing lambs weighing $30 \mathrm{~kg}$ at the commencement of the trial.

TABLE 5

THE MAINTENANCE REQUIREMENT OF SHEEP AND THE ENERGY REQUIRED TO DEPOSIT $1 \mathrm{~g}$ OF FAT OR OF PROTEIN ESTIMATED FROM THE REGRESSIONS OF FAT AND PROTEIN INTAKE ON ENERGY INTAKE

\begin{tabular}{|c|c|c|c|c|}
\hline Author & Diet & $\begin{array}{l}\text { Estimated } \\
\text { for } \\
\text { maintenance } \\
\mathrm{kJ} / \mathrm{kg} \mathrm{w}^{0.75}\end{array}$ & $\begin{array}{c}\text { values of energy } \\
\text { for } \\
\text { depositing } \\
1 \mathrm{~g} \text { fat }\end{array}$ & $\begin{array}{l}\text { required } \\
\text { for } \\
\text { depositing } \\
\text { l g protein }\end{array}$ \\
\hline$\phi_{\text {rskov and }}$ & Barley & & & \\
\hline $\begin{array}{l}\text { McDonald } \\
(1970)\end{array}$ & $\begin{array}{l}+ \\
\text { soya }\end{array}$ & 420 & 48 & 68 \\
\hline \multirow{3}{*}{$\begin{array}{l}\text { Rattray and } \\
\text { Joyce } \\
(1976)\end{array}$} & $\begin{array}{l}\text { Autumn } \\
\text { pasture }\end{array}$ & 786 & 71 & 110 \\
\hline & $\begin{array}{l}\text { Spring } \\
\text { pasture }\end{array}$ & 473 & 42 & 131 \\
\hline & $\begin{array}{c}\text { Dried grass } \\
+ \text { barley }\end{array}$ & 394 & 31 & 130 \\
\hline Bickel and & Hay & & & \\
\hline $\begin{array}{l}\text { Durrer } \\
(1974)\end{array}$ & $\begin{array}{c}+ \\
\text { potatoes }\end{array}$ & 402 & 39 & 67 \\
\hline
\end{tabular}

The sets of data in Table 5 are not readily reconciled; they show two-fold variation in each of the parameters $a, b_{1}$ and $b_{2}$, a much greater variation than has been noted in similar work with pigs.

Despite these difficulties of estimating $b_{1}$ and $b_{2}$, it seems likely, in view of the evidence from other species that the efficiency of utilisation of energy for fat deposition and protein deposition differ, that the same is true of cattle. Calculations can be made of their likely effects. If the mean efficiencies in non-ruminants are 0.70 for fat synthesis from metabolisable energy and 0.45 for protein synthesis, then they are likely to be lower in ruminants by the inverse ratio of the metabolisable energy cost of synthesising ATP from ADP in the two classes of animal, i.e. in the ratio of about 96-84 kJ/mole (KielanowsKI, 1976). Corresponding efficiencies for ruminants would thus be 0.615 for fat and 0.394 for protein. The efficiency of cnergy utilisation above maintenance in ruminants might thus be expected to range from a minimum of about 0.52 for gains in young intact male animals in which the ratio by weight of protein to fat is 1 protein: 0.75 fat (55 per cent of energy retained as fat) to 0.59 for mature female animals in which the weight ratio of 
protein to fat is $1: 5$ (90 per cent of energy retained as fat). This range of variation cannot account for the observed variation in efficiencies in calorimetric experiments or indeed in comparative slaughter trials.

In support of this BLAXTER et al. (1966) failed to show any change in efficiency of utilisation of metabolisable energy above maintenance in cattle given the same diet at different ages, although, admittedly, the range in the composition of gains was small. Also in support are the experiments of BOUVIER and Vermorel (1975) in which the same diet was given to 3-month old lambs and to 4-year old sheep. At similar energy retentions of $200 \mathrm{~kJ} / \mathrm{kg} \mathrm{W}^{0.75}$ lambs retained 23 per cent of energy as protein but adults retained only 6.9 per cent. The efficiencies of utilisation of metabolisable energy above maintenance were 0.44 for adults and 0.46 for lambs, a difference in the wrong direction to substantiate the hypothesis, but in any event not significant statistically. Similar results were obtained when 5 to 8 -month old calves were compared with mature sheep (VERMOREL et al., 1979).

Even so, there is evidence that as between cattle of different breeds and sexes depositing different proportions of energy as protein there appears to be a correlation between efficiency of utilisation of metabolisable energy above maintenance and the proportion of energy retained as protein. This has been noted by GEAY et al. (1979) in comparisons between bulls and heifers, by Ayala (1974) in comparisons between bulls, heifers and steers, and by RoHR and DAENICKE (1978) in comparisons of Friesian and Simmental bulls. Table 6 summarises Ayala's data.

TABLE 6

MEAN RESULS OF AYALA:S (1974) EXPERIMENT - GROWTH FOR 224 DAYS

\begin{tabular}{|c|c|c|c|}
\hline \multicolumn{2}{|c|}{$\begin{array}{l}\text { Breed and sex } \\
\text { of animal }\end{array}$} & 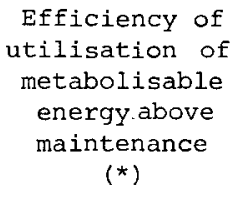 & $\begin{array}{l}\text { Proportion } \\
\text { of protein } \\
\text { energy in } \\
\text { gains } \\
(* *)\end{array}$ \\
\hline \multirow[t]{3}{*}{ Aberdeen Angus } & bulls & 0.414 & 0.27 \\
\hline & steers & 0.483 & 0.20 \\
\hline & heifers & 0.653 & 0.13 \\
\hline \multirow[t]{3}{*}{ Holstein } & bulls & 0.379 & 0.45 \\
\hline & steers & 0.407 & 0.40 \\
\hline & heifers & 0.450 & 0.28 \\
\hline
\end{tabular}

* From AYALA'S Table 57

* From ayala's Table 58

Regression analysis of these results suggests that :

Efficiency of utilisation of $\mathrm{ME}=0.667-0.705 p \ldots \ldots \ldots$

where $p$ is the proportion of energy deposited as protein. The regression is significant statistically when $P=0.05$. and indicates that the efficiency of deposition of 
fat is 0.667 and of protein is negative. If the very high value for Aberdeen Angus steers is omitted, the efficiencies for fat deposition and protein deposition are 0.54 and 0.19 respectively. As pointed out by RoBELIN and GEAY (1976) in explaining the positive association they found in growing Limousin bulls between efficiency and the proportion of energy retained as fat, the use of body weight raised to the power 0.75 as a scaling factor could be responsible for their own and others' findings. They showed that direct proportionality of maintenance requirement to body weight removed the variation of $k_{f}$ with the protein content of the gain. This view has much in common with that of WEBSTER (1978) who pointed out that the relationship between heat production and body weight is not independent of growth rate.

\section{Conclusions}

There is little doubt that the efficiency of utilisation of metabolisable energy by growing and fattening ruminants defined as the slope of the line relating energy retention to metabolisable energy intake is not constant. Much effort has been spent to find the factors which affect it. One approach is to regard the efficiency as being uniquely determined by dietary factors - the metabolisability of the energy of the diet, its protein content or its fibre content - as exemplified by the approach given by BLAXTER and BOYNE (1978). The approach implies that energetic efficiency is not affected by the composition of the gain made ; the composition of the gain, that is its heat of combustion, is only taken into account in converting energy retention to body weight gain. The other approach stems from the work of KiELANOWSKI with pigs and states that variation in efficiency can be accounted for by variation in the proportion of protein (or of fat) in the gain the animal makes. Present estimates of the efficiencies of fat and protein deposition in ruminants are extremely imprecise.

If it is assumed that they are similar to those in simple-stomached species then calculation shows that the variation in efficiency noted in many trials cannot be accounted for. Some experiments comparing ruminants given the same diet but retaining different proportions of energy as protein show no differences in efficiency attributable to differences in the protein content of gain. Other experiments, however, show such differences may exist. The latter experiments can in some instances be criticised in that they are particularly sensitive to the ways with which maintenance energy requirements are estimated.

It seems reasonable to conclude that it is probable that composition of gain is a determinant of efficiency in cattle as it appears to be in pigs, but that its extent has not yet been fully explored or separated from dietary factors. The second approach thus cannot yet be used in any precise way to estimate body gain from feed intake. The data presented and the success of many feeding systems based on the premise that under most practical circumstances efficiency is solely determined by dietary factors suggest that the first approach results in good prediction of rate of gain in conventional cattle. Whether this approach is as effective in predicting gain in fast growing bulls of very lean breeds as it is in predicting gain in British beef animals remains to be tested. If good prediction equations are formulated relating the energy density of gain to body weight and to rate of gain in such animals then this could and should be done. 


\section{References}

ARC. 1965. The Nutrient Requirements of Farm Livestock. No. 2 : Ruminants. London, ARC.

Ayala H., 1974. Cornell University PhD Thesis. University Microfilms, Ann Arbor.

Berschauer F., Gaus G., Menke K.H., 1979. Proc. 8th Symposium on Energy Metabolism. EAAP Pubn.

Bickel H., DurRer A., 1974. Proc. 6th Symposium on Energy Metabolism. EAAP Pubn. No. 14, p. 119.

Blaxter K.L., Boyne A.W., 1978. J. agric. Sci., Camb. 90, 47.

Blayter K.L. Clapperton J.L., Wainman F.W., 1966. J. Agric. Sci., Camb. 67, 67.

Blaxter K.L., Graham N. McC., 1955. J. agric. Sci., Camb. 46, 292.

Bouvier J.C., Vermorel M., 1975. Ann. Zootech., 24, 697.

Geay Y., Robelin J., Vermorel M. 1979. Proc. 8th Symp. on Energy Metab. EAAP Pubn.

JARRIGE R., 1978. Principes de la nutrition et de l'alimentation des ruminants. Versailles, I.N.R.A.

Kielanowski J., 1976. In : Protein Metabolism and Nutrition (Ed. D.J.A. Cole, K.N. Boorman, P.J. ButTery, D. Lewis, R.J. Neale and H. Swan), p. 267. London, Butterworths. Lofgreen G.P., Garrett W.N., 1968. J. Anim. Sci., 27, 793.

MAFF, DaFs, DaNi, 1975. Energy Allowances and Feeding Systems for Ruminants : Tech. Bull., 33, London, HMSO.

MUller H.L., KIRCHGESSNER M., 1979. Z. Tierphysiol. Tierernahrung u. Futtermittelkunde, 42, 161.

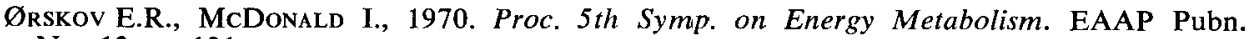
No. 13, p. 121.

Pullar J.D., Webster A.J.F., 1977. Br. J. Nutr., 37, 355.

Rattray P.V., Joyce J.P., 1976. N.Z. J. Agric. Res., 19, 299.

Robelin J., GeaY Y., 1976. Proc. 7th Symp. on Energy Metabolism. EAAP Pubn. No. 19, p. 213.

RoHR K., Daenicke R., 1978. In : Pattern of Growth and Development in Cattle (Ed. H. DE Boer and J. Martin), p. 413. The Hague : Martinus Nijhoff.

Schiemann R., Nehring K., Hoffmann L., Jentsch W., Chudy A., 1971. Energetische Futterbewertung und Energienormen. Berlin, Dtsh Akad Landw.

VAN Es A.J.H., 1975. Livestock Prod. Sci., 2, 95.

Van Es A.J.H., 1978. Livestock Prod. Sci., 5, 331.

Vermorel M., Bouvier J.C., Geay Y., 1979. Proc. 8th Symp. on Energy Metabolism. EAAP Pubn.

WEBSTER A.J.F., 1978. World Rev. Nutr. Diet., 30, 189. 


\section{Discussion}

\section{Chair : A. NeImann-SørEnSEN (Denmark)}

H. RefsGaARD Andersen (Denmark). - I have some comments on figure 9 shown by Dr. Bickel. I would like to show some slides concerning the relationship between feed conversion ratio (energy per $\mathrm{kg}$ liveweight gain) and feeding levels. I have some results here where we had feeding levels from 100 per cent down to 66 per cent and we have calculated the feed conversion ratios. The figures $I$ am showing are from early or medium maturing breeds, mostly Friesians. In almost all cases, when we decrease the feeding level then we also decrease the feed conversion ratio. In an experiment from Holland, where they decreased the feeding level from 100 per cent to 64 per cent, the best feed conversion ratios were at 64 per cent. A Danish experiment and some experiments from Israel and France show the same result. The results could be influenced by breed or by weight. Therefore, perhaps I could just mention some preliminary results from an experiment in an EEC project which involves different breeds crossed with Red Danish and Danish Friesian bulls. Three feeding levels : ad libitum, 85 per cent and 70 per cent were used, and the animals were slaughtered at different weights. The results show that at a low liveweight we have almost the same feed conversion ratio $\mathrm{SFU} / \mathrm{kg}$ liveweight gain, independent of feeding levels. At liveweights from 250 to $350 \mathrm{~kg}$, we have a trend for fast growing animals to have the best feed conversion ratio at the highest feeding levels. However, when we have higher liveweights, from 350 to $450 \mathrm{~kg}$, we have an increase in feed conversion ratio with increased feeding level. With higher weights it is even more extreme.

H. BICKEL (Switzerland). - I will try to comment and give an interpretation. It is always very difficult to interpret feed conversion ratios, as long as you do not know the amount of fat and protein which is deposited in the gain. The curve which I showed was just a mathematical calculation. If you do not know the energy concentration of the gain, you do not know if it is changing. You know that with the last $200 \mathrm{~kg}$ you put on the steer or the heifer, fat deposition is higher than protein deposition, so certainly energy value of the gain will increase. Dr. Andersen showed that the effect of putting more fat in is more important than the effect in the feeding level. That is some explanation as to why we find higher feed conversion ratios at the end of the fattening period. On the other hand, at lower liveweights of $100-200 \mathrm{~kg}$, with the higher feeding level more protein is laid down and less fat, especially in the case of bulls, as opposed to the contrary when the feed conversion ratio is going down. In his tables, Dr Andersen showed us this typical Charolais effect, where the feed conversion ratio does not even move. He showed that it was 100 per cent, then 99 per cent, then 98 per cent. What $I$ want to stress is that it is very difficult, and even dangerous, to interpret experiments in terms of feed conversion ratio in the absence of information about the fat and protein content of gains on the one hand, and not enough about the partial efficiency for growth. Thirdly, as we said yesterday, there is also a shift in the maintenance requirement. I would say the fourth factor is that if you calculate the feed efficiency ratio in feed units per $\mathrm{kg}$ liveweight gain, the constant net energy of fattening at different feeding levels introduces further complications. So that is the fourth area where you have differences and which makes it very difficult to give a real, direct interpretation.

H. Refsgand Andersen. - I should say that in this last experimenta I mentioned we had the same energy concentration in the ration at the different feeding levels.

J. L'Estrange (Ireland). - Dr Andersen, can you tell us what is the intake, your 100 per cent versus your 65 per cent ? Is it based on intake per unit of body weight? Secondly, what is the rate of gain?

H. RefsgaARd Andersen. - I do not have all the results here but the feeding levels are in Scandinavian Feed Units per day. For example, at $400-450 \mathrm{~kg}$ it increases from about $5 \mathrm{SFU} /$ day (60 per cent) to a little more than 8 (100 per cent). At the lower weight, it increases from 4 SFU (60 per cent) up to about 6.5 SFU (100 per cent). 
H. BICKEL. - What is the dimension of your basal line ?

H. Refsgatad Andersen. - Scandinavian Feed Units. It is intake per head per day. I cannot see that it makes any difference whether we calculate in Scandinavian Feed Units or in your system, or in the system from Holland.

J. L'EsTRANGE. - What is the liveweight gain ?

H. RefsgaArd Andersen. - I do not have the results on liveweight gain here. Liveweight gains depend on the weight of the animal and also on the breed. For example, Charolais have a very high growth capacity. They grow 1400 to $1500 \mathrm{~g} /$ day on the highest feeding level.

A.J.H. VAN Es (The Netherlands). - Did you measure the digestibility of the ingredients of the rations fed to those animals?

H. Refsgaard Andersen. - We do not have the digestibility of the rations but only the chemical composition of the feeds. I can say that it was a ration of concentrate only and a small amount of straw. On the restricted feeding we had the same amount of straw. It would be almost the same energy concentration independent of feeding levels.

A.J.H. VAN Es. - If you look at the data from Vermorel, in the young growing animal he shows a rather different digestible energy : metabolisable energy ratio than in the case of an older one. I think one has to measure at least digestible energy during such trials in order to interpret more closely what is really happening. In fact, the Scandinavian Feed Unit does not tell us much if you have computed it in this way.

H. RefsgaARd ANDERSEN. - We feel that we can establish energy standards for growth from feeding experiments with different energy levels and for animals slaughtered at different weights. We measure the carcase quality and meat quality but we do not make analyses of the caloric content of the carcase. I believe there is a disagreement between the energy standards used in different countries and what we find in feeding experiments. I think it is very important that we should have agreement on these things.

Sir KenNeth Blaxter $(U K)$. - In the classical energy metabolism experiments, if you look at energy retained and feed energy ingested, say it is in gross energy, it is just as Dr. Bickel indicated, a situation that comes up to an asymptote and then declines very slowly. Maximal appetites of animals for diets of different quality are usually less than the amounts that have to be consumed at the asymptote. So, as far as energy retention is concerned, there is very, very rarely a situation in which total efficiency in terms of energy retention would show a decline with increasing level of nutrition. I think the only way in which this can occur is the change in the composition of the gain made because you are simply measuring body weight change which is the fat and protein together. I do not think that it has anything at all to do with energetic efficiency.

H. Refsgatid Andersen. - I agree.

Sir Kenneth Blaxter. - Why then did you say that there is a difference between the energy feeding standard people and the practical people?

H. Refsgand Andersen. - - It was because yesterday I presented the feeding standards from different countries. The feeding standards from most countries show that when we decrease the feeding level the feed conversion ratio (energy/kg gain) increases.

G. Alderman $(U K)$. - No, that is not a fair conclusion. Your method of express.ng our information confuses the proportion of energy above maintenance with the proportion going into maintenance. Your choice of Ration 1 as your base, which is a high plane of nutrition. over $1 \mathrm{~kg}$ of gain/day, inevitably means that as we go down to lower rates of gain, the proportion of retained energy becomes a smaller proportion of maintenance and the feed conversion ratio is bound to increase. However, to comment more specifically on the question you pose, the changes in energy value of gain in the UK information is much less than that we know occurs in fact. A practical feeding trial will come up with different conclusions from what our current standards show. I still think that your method of expression here is trapping us into conclusions which are not, in fact, what you think they are. 
H. RefsgaARd Andersen. - But according to your feeding standards you have increasing feed conversion ratios with decreasing feeding levels. I am not talking about retained fat, I am only talking about what your standards show when you decrease the feeding levels - that your feed conversion ratios are increased. That is why I showed some feeding results which showed just the opposite.

G. Alderman. - - But it must be the case that as you go to low rates of gain your feed conversion ratio becomes asymptotic to infinity. At maintenance, your feed conversion ratio is infinite.

H. Refsgaard Andersen. - Yes. At a very low feed intake the FCR are increasing with decreasing energy intake as shown in the figure :

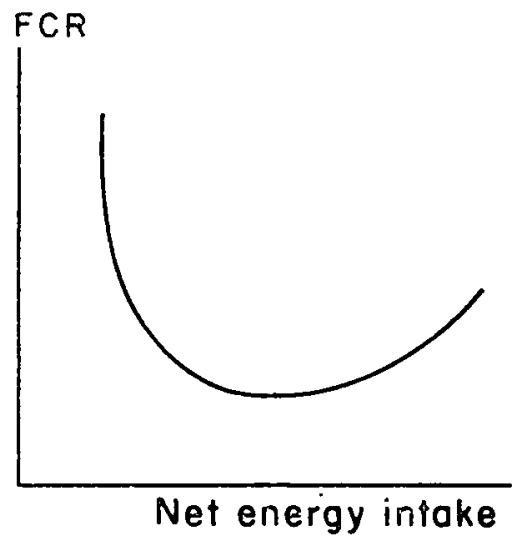

However, according to most feeding experiments, using early and moderate maturing breeds with a liveweight between 250 and $600 \mathrm{~kg}$, the $\mathrm{FCR}$ increases with increasing intensity. Possibly it is not the case for late maturing breeds and for animals weighing less than $200-300 \mathrm{~kg}$.

A. Neimann-SøRENSEN. - I think this curve has brought some clarification between the two views. However, perhaps it would be appropriate now to broaden the discussion.

Y. GeAY (France). - I have a remark to make to Sir Kenneth. I was surprised by the fact that you used a linear relationship between $k_{f}$ and the percentage of energy retained as protein $x$ because this relationship is not linear, it is curvilinear.

If you assume the ratio:

$$
\frac{\mathrm{NE}}{k_{f}}=\frac{\mathrm{LE}}{k_{1}}+\frac{\mathrm{PE}}{k_{p}}
$$

this relationship leads to:

$$
\begin{gathered}
\frac{1}{k_{f}}=\frac{\mathrm{LE}}{\mathrm{NE}} \cdot \frac{1}{k_{1}}+\frac{\mathrm{PE}}{\mathrm{NE}} \cdot \frac{1}{k_{p}} \text { if } x=\frac{\mathrm{PE}}{\mathrm{NE}} \\
\frac{1}{k_{f}}=\frac{1-x}{k_{1}}+\frac{x}{k_{p}} \quad \text { or } \quad k_{f}=\frac{k_{1} \cdot k_{p}}{x\left(k_{1}-k_{p}\right)+k_{p}}
\end{gathered}
$$

similar to $\quad \frac{\mathrm{A}}{\mathrm{B} x+c}$

It is not a linear relationship. I agree with you that the differences in $k_{f}$ can be explained by the $q$ value and there is no doubt that the $q$ value has a great influence. However, at the same $q$ value, if we consider different kinds of animals, even allowing for differences in maintenance requirements, it seems that there are some differences in feed efficiency.

R. JARRIGE (France). - I would like to put on the blackboard the daily rates of protein accretion in some types of animal. 


$\begin{array}{cccc} & \text { Friesian } & \text { Charolais } & \\ & \mathbf{g} & \mathrm{g} & \\ \delta & 180 & 250 & \\ \& & 130 & 190 & \mathrm{~g} \text { protein deposition/day } \\ \wp & 120 & 170 & \end{array}$

These figures relate to animals of a liveweight of $350 \mathrm{~kg}$ fed ad libitum with a high energy diet so they can express their genetic potential for protein accretion. If they are fed this high density diet ad libitum, generally the dry matter intake is not very different between these kinds of animals. Generally Charolais have a slightly lower intake than Friesian. So, from these differences in protein accretion in contrast with no differences in energy intake, utilisation of energy by the different animals should be different. I think some very stimulating controversy derives from the fact that some experiments have used a standard animal, whilst in our slaughter work, as in Denmark and probably in Germany, we used a large range of animals.

H. J. OsLage (Federal Republic of Germany). - I would like to address a question to Dr. Geay. You have just demonstrated the decrease in $k_{p}$ for growth with increasing protein in the daily gain. This means with younger animals and is in accord with our theory of the differences in the value of $k_{p}$ and $k_{f}$ and with questions of turnover and so on. But how would you explain that we find just the opposite results with pigs? There is no doubt that we have a lot of experiments showing that we have the higher values for utilisation of energy for growth with younger piglets than we have with older pigs. I cannot explain this difference, nor the different behaviour of monogastrics and ruminants in this direction. I would be grateful if you could offer an explanation.

Y. GeaY. - Are you sure that the difference is due to the type of animals and not due to the estimation of maintenance requirements?

H.J. OsLage. - You can run your calculations with different values for maintenance requirement. Even if you calculated a higher maintenance requirement for the piglets... you would have a better efficiency.

Y. GeAY. - It has been shown by Dr. Webster that heat production is higher with young animals than with older ones.

M. Vermorel (France). - Several workers have shown that ME efficiency for growth is higher in very young animals than in older ones. It has been shown that in growing lambs the turnover rate changes with the age of the animals. There are steps in the growth of animals where the turnover rate decreases and other steps where it increases. So perhaps these differences in efficiency could be linked to this aspect. Of course, it is just an hypothesis. We do not have enough data to say definitely. 